\title{
The genetic control of host responses to Dipetalonema viteae (Filarioidea) infections in mice
}

\author{
N.STOREY, D.WAKELIN \& J.M.BEHNKE \\ MRC Experimental Parasitology Research Group, Department of \\ Zoology, University of Nottingham, Nottingham, UK
}

Accepted for publication 26 November 1984

\begin{abstract}
Summary Dipetalonema viteae (Filarioidea) infections were established in inbred strains of mice by the s.c. implantation of adult female worms and the resulting microfilaraemia and adult worm survival monitored. BALB/c mice were the most susceptible strain examined, showing a high level microfilaraemia of approximately 6 month's duration. $\mathrm{C} 57 \mathrm{Bl} / 10, \mathrm{CBA} / \mathrm{Ca}$ and $\mathrm{C} 3 \mathrm{H} / \mathrm{He}$ mice were all equally resistant to infection, showing a low level of microfilaraemia of approximately 1 month's duration. The response of NIH mice was intermediate. Relatively little strain difference was seen in adult worm survival although worms lived slightly longer in $\mathrm{C} 57 \mathrm{Bl} / 10$ mice than in $\mathrm{BALB} / \mathrm{c}$ mice. The adult females became depleted of microfilariae over a period of approximately 1 month before becoming encapsulated in host tissue. Challenge infections given to mice previously implanted with worms resulted in lower level, shorter lasting microfilaraemias than those seen in the initial primary infections. All strains showed immunity when challenged. High responsiveness (resistance) was inherited as a dominant trait in $F_{1}$ hybrids produced by crossing high and low responder strains. Genes linked with the major histocompatability complex $(\mathrm{H}-2)$ were found to have no effect on the response phenotype as demonstrated by the similar responses of $\mathrm{H}-2$ congenic mice on the $\mathrm{BALB} / \mathrm{c}$ or $\mathrm{C} 57 \mathrm{Bl} / 10$ backgrounds. The response phenotype of radiation chimaeras was determined by the phenotype of the donor from which bone marrow (BM) cells were taken for reconstitution. Susceptible BALB/c mice reconstituted with resistant $\mathrm{B} 10 \mathrm{D} 2 / \mathrm{n}$ BM behaved identically to the donor strain, indicating that the genetic variation which exists between mouse strains in their responses to D. viteae is expressed through a population of BM derived cells and is not simply a consequence of host structure or physiology.
\end{abstract}

Keywords: Dipetalonema viteae, mice, genetics, inheritance, major histocompatibility complex, radiation chimeras, immunity

\section{Introduction}

The influence of host genetic factors on susceptibility or resistance to parasitic infection has now been demonstrated in a wide variety of host-parasite systems (Wakelin 1978). In

Correspondence: Dr J.M. Behnke, MRC Experimental Parasitology Research Group, Department of Zoology, University of Nottingham, Nottingham NG7 2RD, UK. 
human filariasis, there is a great deal of observational (Low 1908, Ogilvie \& MacKenzie 1981) and some experimental data (Piessens et al. 1980) to show that susceptibility to infection and liability to pathological sequaleae vary markedly between individuals in the same endemic region. If it can be assumed that, in these regions, each individual is equally exposed to infection, then it can be concluded that such variations must reflect the effect of host genetic factors upon the outcome of infection. This conclusion is supported by the observation of familial clusterings of filarial disease (Ottesen et al. 1981) where this clustering is most compatible with genetic transmission of disease susceptibility. Variations in host responses to filarial infections have also been noted in laboratory animals, for example with Dipetalonema viteae in hamsters (Neilson 1978) and mice (Haque et al. 1980), Brugia pahangi in rats (Gusmao, Stanley \& Ottesen 1981; Fox \& Schacher 1976; Cruickshank et al. 1983) and Brugia malayi in mice (Fanning \& Kazura 1983). However, the reasons underlying variation in host responses have received little attention and are inadequately explained. In part, this is because the analysis of host-parasite immunogenetics requires the use of hosts which are well defined both immunologically and genetically and there are few experimental systems where filarial worms will develop in mice and rats (Philipp et al. 1984). Consequently, there is a valid requirement to use mice as proxy hosts, i.e. to infect them by transfer of adult or microfilarial stages of the parasites. One such proxy system is the Dipetalonema viteae/mouse model (Haque et al. 1980) in which adult worms are implanted s.c. into mice and a patent microfilaraemia established. These workers noted host strain variations especially in terms of microfilaraemia but also adult worm survival. The present investigation has used this system to examine variations between inbred, hybrid and congenic mice in order to analyse the genetic basis of differential response to infection. An initial analysis of the mechanism through which this genetic variation is expressed has been made using radiation chimaeras.

\section{Materials and methods}

\section{Experimental design}

A panel of inbred mouse strains was used to determine whether the course of infection following implantation with female $D$. viteae showed genetically determined variations. Microfilaraemia and adult worm survival during a primary infection and the response to a challenge infection were determined. The most susceptible and resistant strains of mice were selected and crossed to give $F_{1}$ hybrids, which were then used to study the mode of inheritance of response phenotype. Congenic strains of mice on the genetic backgrounds of the resistant and susceptible strains were then used to assess the influence of the H-2 (MHC) haplotype. Radiation chimaeras between susceptible and resistant H-2 compatible strains were used to assess the expression of genetic control through bone marrow (BM) derived cells.

\section{Animals}

Inbred female mice obtained from Olac $1976 \mathrm{Ltd}$ were used and are listed in Table 1. $\mathrm{F}_{1}$ hybrids $(\mathrm{NIH} \times \mathrm{B} 10, \mathrm{NIH} \times \mathrm{B} 10 . \mathrm{G}$ and $\mathrm{BALB} / \mathrm{c} \times \mathrm{B} 10)$ were bred in the Department of Zoology, Nottingham University, as were jirds and inbred DSN hamsters. 
Table 1. List of mouse strains with their $\mathrm{H}-2$ haplotype and the abbreviations used in this paper

\begin{tabular}{lcl}
\hline Strain & $\begin{array}{c}\text { H-2 } \\
\text { haplotype }\end{array}$ & $\begin{array}{c}\text { Abbreviation } \\
\text { used }\end{array}$ \\
\hline BALB/c/01a & d & BALB/c \\
BALB/b/01a & b & BALB/b \\
BALB/k/01a & k & BALB $/ \mathrm{k}$ \\
CBA $/ \mathrm{Ca} / 01 \mathrm{a}$ & $\mathrm{k}$ & $\mathrm{CBA}$ \\
$\mathrm{C} 3 \mathrm{H} / \mathrm{He} / 01 \mathrm{a}$ & $\mathrm{k}$ & $\mathrm{C} 3 \mathrm{H}$ \\
$\mathrm{C} 57 \mathrm{BL} / 10 / \mathrm{ScSn} / 01 \mathrm{a}$ & $\mathrm{b}$ & $\mathrm{B} 10$ \\
$\mathrm{~B} 10 . \mathrm{D} 2 / \mathrm{n} / 01 \mathrm{a}$ & $\mathrm{d}$ & $\mathrm{B} 10 . \mathrm{D} 2 / \mathrm{n}$ \\
$\mathrm{B} 10 . \mathrm{BR} / 01 \mathrm{a}$ & $\mathrm{k}$ & $\mathrm{B} 10 . \mathrm{BR}$ \\
$\mathrm{B} 10 . \mathrm{G} / 01 \mathrm{a}$ & $\mathrm{q}$ & $\mathrm{B} 10 . \mathrm{G}$ \\
$\mathrm{N} 1 \mathrm{H} / 01 \mathrm{la}$ & $\mathrm{q}$ & NIH \\
\hline
\end{tabular}

\section{Parasites}

Dipetalonema viteae was cyclically maintained in jirds (Meriones unguiculatus) and the tick Ornithodorus moubata (Worms, Terry \& Terry 1961).

Ticks were infected by feeding them on the abdomen of anaesthetised jirds showing a microfilaraemia of 20-40 microfilariae (Mf) $/ 10 \mu \mathrm{l}$. Four to six weeks later the ticks were dissected in RPMI 1640 medium containing penicillin and streptomycin $(100 \mathrm{u} / \mathrm{ml})$ in order to collect infective $\left(\mathrm{L}_{3}\right)$ larvae. Approximately $300 \mathrm{~L}_{3}$ were injected s.c. into the groin of male, inbred DSN hamsters. Ninety-six days later (at peak microfilaraemia) the hamsters were killed and skinned. Adult worms were removed from the pelt and carcass using fine forceps and transferred into RPMI 1640 (containing antibiotics) at $37^{\circ} \mathrm{C}$. They were sexed and inspected for damage prior to transfer.

\section{Implantation of adult $\mathrm{D}$. viteae}

Six to ten week old mice were anaesthetised with pentobarbitone sodium and the right flank shaved and surface sterilized with $70 \%$ alcohol. A 5-10 mm incision was made and a s.c. pocket created by inserting the tips of a pair of blunt forceps. Using blunt forceps, the worms were gently inserted into the pocket and the wound closed with silk sutures. The area was then dressed with antibiotic spray (polymixin/bacitracin/neomycin) and sealed with plastic skin (Nobecutane). Mice were allowed to recover, given food and water (containing the antibiotic oxytetracycline hydrochloride $165 \mathrm{mg} / \mathrm{l}$-Terramycin, Pfizer Ltd) ad libitum, and housed under conventional animal house conditions in groups of six.

\section{Microfilaraemia}

Duration and level of microfilaraemia was monitored for each recipient mouse. A $10 \mu 1$ blood sample was obtained from the retro-orbital venous plexus of ether anaesthetised 
animals. The blood was expelled onto the surface of a clean, grease free microscope slide and spread into an area $10 \times 20 \mathrm{~mm}$. After air drying overnight, the smear was dehaemoglobinized in $1 \%$ acetic acid, fixed in methcol, stained with Mayer's haemalum and blued in tap water. Microfilariae were counted microscopically and the number of microfilariae per $10 \mu \mathrm{l}$ blood expressed as a geometric mean using a $\log x+1$ transformation. Microfilaraemia was considered extinct when $2 / 3$ of the mice had been microfilariae negative for two successive bleeds. Challenge infections of five female worms were given to mice when the primary infection had been cleared. Age matched naive control mice were given similar infections at the same time.

\section{Radiation chimaeras}

Recipient mice were irradiated with approximately $900 \mathrm{rad}$ of gamma irradiation using the Nottingham University ${ }^{60} \mathrm{Co}$ source (output $\sim 2700 \mathrm{rad} / \mathrm{h}$ ). BM cell suspensions were prepared from the long bones of donor mice and adjusted to approximately $5 \times 10^{7}$ cells $/ \mathrm{ml}$ in Hanks' balanced salt solution with heparin $(5 \mathrm{iu} / \mathrm{ml})$. Between 1 and $2 \times 10^{7}$ cells were injected i.v. into the lateral tail veins of recipients within $3 \mathrm{~h}$ of irradiation. Recipient mice were allowed to rest for 90 days to ensure the donor BM graft had replaced all BM derived cells. Irradiated mice were given Terramycin in their drinking water.

\section{Results}

\section{Microfilaraemia in inbred mouse strains}

Five adult female $D$. viteae were implanted s.c. into each of six female mice per strain and the mice were then bled between one and three times a week. The results, in terms of peak microfilaraemia and duration are shown in Table 2. Mf were first seen in the peripheral blood at 2 days post-infection in all strains. Peak microfilaraemia occurred between days 4 and 10 in $\mathrm{B} 10, \mathrm{CBA}$ and $\mathrm{C} 3 \mathrm{H}$ mice with mean values ranging from 10 to $14 \mathrm{Mf} / 10 \mu \mathrm{l}$. Thereafter, the microfilaraemia declined and was extinct by day 30 in B10 and day 58 in $\mathrm{CBA}$ and $\mathrm{C} 3 \mathrm{H}$. In contrast, microfilaraemia reached a much higher level in BALB/c mice peaking at a mean of $323 \mathrm{Mf} / 10 \mu \mathrm{l}$. This peak occurred between days 19 and 56 for individual animals and microfilaraemia was not extinct until about day 180 post-infection. NIH mice showed an intermediate pattern, reaching a peak of $89 \mathrm{Mf} / 10 \mu$ at day 23 post-infection which declined to extinction at around 63 days post-infection.

\section{Microfilaraemia in challenge infections}

Upon extinction of microfilaraemia, B10, BALB/c and NIH mice were challenged with a further five female worms (Table 3). The observed microfilaraemias were of lower level and of shorter duration than in the primary infection for each strain. The microfilaraemia in age-matched challenge control mice was higher and longer in duration than in the challenged mice but did not normally reach the levels seen in the initial primary infection. This age-linked difference was particularly marked in the B10.G, B10.BR and BALB/k strains. 
Table 2. Microfilaraemia in various mouse strains, congenic strains and $F_{1}$ hybrids following the s.c. implantation of five female D. viteae

\begin{tabular}{|c|c|c|c|c|c|}
\hline \multirow[b]{2}{*}{ Strain } & \multirow{2}{*}{$\begin{array}{c}\mathrm{H}-2 \\
\text { haplotype }\end{array}$} & \multicolumn{2}{|c|}{$\begin{array}{l}\text { Microfilaraemia } \\
\text { (Mf/101 blood) }\end{array}$} & \multicolumn{2}{|c|}{$\begin{array}{c}\text { Duration of } \\
\text { microfilaraemia (days) }\end{array}$} \\
\hline & & Peak* & Range $\dagger$ & Duration $\ddagger$ & Range§ \\
\hline $\mathrm{BALB} / \mathrm{c}$ & d & 323 & $293-438$ & 180 & 140-200 \\
\hline $\mathrm{B} 10 . \mathrm{D} 2 / \mathrm{n}$ & d & 15 & $12-46$ & 56 & $25-63$ \\
\hline $\mathrm{BALB} / \mathrm{b}$ & $\mathrm{b}$ & 252 & $192-694$ & 202 & $156-218$ \\
\hline B10 & $\mathrm{b}$ & 14 & $9-31$ & 30 & $20-44$ \\
\hline $\mathrm{BALB} / \mathrm{k}$ & k & 266 & $289-389$ & 238 & $127-265$ \\
\hline B10.BR & k & 19 & $24-82$ & 63 & $29-77$ \\
\hline CBA & k & 10 & $3-39$ & 58 & $12-60$ \\
\hline $\mathrm{C} 3 \mathrm{H}$ & k & 11 & $10-59$ & 58 & $24-60$ \\
\hline NIH & $\mathrm{q}$ & 89 & $61-300$ & 63 & $44-65$ \\
\hline B10.G & q & 48 & $27-201$ & 49 & $26-64$ \\
\hline$(\mathrm{NIH} \times \mathrm{B} 10 . \mathrm{G}) \mathrm{F}_{\mathrm{I}}$ & qq & 34 & $14-98$ & 49 & $21-64$ \\
\hline$(\mathrm{NIH} \times \mathrm{B} 10) \mathrm{F}_{1}$ & $\mathrm{qb}$ & 17 & $3-35$ & 28 & $9-29$ \\
\hline$(\mathrm{BALB} / \mathrm{c} \times \mathrm{B} 10) \mathrm{F}_{1}$ & $\mathrm{db}$ & 42 & $33-50$ & 22 & $14-22$ \\
\hline
\end{tabular}

* Peak refers to the peak geometric mean.

$\dagger$ Range refers to the range of peak microfilaraemias recorded for individual mice. $\ddagger$ Duration refers to the period from infection to the point where $2 / 3$ of the mice were amicrofilaraemic.

$\S$ Range refers to the shortest and longest microfilaraemias recorded for individual mice. Bold writing indicates a positive microfilaraemia at the termination of the experiment.

\section{Adult worm survival}

BALB/c and B10 mice were implanted with five female worms and, on days 17, 22, 27, 32 , 37 and 50 post-infection, groups of two to four mice were killed and dissected to recover adult worms.

At post-mortem, worms were generally to be found either beneath the dorsal skin or in the axillae. On single occasions a worm was found in the peritoneum and the thoracic cavity.

At day 17 , the worms recovered from both strains were of normal appearance with motile microfilariae in utero. On day 22 the worms were being enclosed by host tissue although there was little cell adherence and healthy worms could be removed with little difficulty. By day 27, in both B10 and BALB/c mice, some of the worms were dead and these were enclosed in soft nodules; some live worms were also in soft nodules. There was obvious depletion of in utero microfilariae and some worms had no Mf. By day 32 all the worms in the BALB/c mice were dead and showed evidence of internal disintegration. No $\mathrm{Mf}$ were visible in utero and the worms were all enclosed in nodules. Some worms in B10 mice were still alive at this time but had no Mf in utero. By day 50 all worms were dead in both strains. 
Table 3. The microfilaraemia in mice following a secondary challenge infection of five female worms

\begin{tabular}{|c|c|c|c|c|c|c|}
\hline \multirow[b]{2}{*}{ Strain } & \multicolumn{3}{|c|}{$\begin{array}{l}\text { Peak microfilaraemia } \\
\text { (Mf/10 } \mu \text { l blood) }\end{array}$} & \multicolumn{3}{|c|}{$\begin{array}{c}\text { Duration of } \\
\text { microfilaraemia (days) }\end{array}$} \\
\hline & Primary* & Secondary ${ }^{\dagger}$ & Control $\ddagger$ & Primary & Secondary & Control \\
\hline BALB/c & 323 & 23 & 169 & 180 & 120 & 180 \\
\hline BALB/b & 252 & 39 & nd & 202 & 63 & nd \\
\hline $\mathrm{BALB} / \mathrm{k}$ & 266 & 39 & 81 & 238 & 106 & 99 \\
\hline B10 & 14 & 4 & 22 & 30 & 22 & 22 \\
\hline B10.BR & 19 & 3 & 6 & 63 & 32 & 30 \\
\hline $\mathrm{B} 10 . \mathrm{D} 2 / \mathrm{n}$ & 15 & 3 & 22 & 63 & 23 & 50 \\
\hline B10.G & 48 & 3 & 7 & 49 & 22 & 29 \\
\hline $\mathrm{NIH}$ & 89 & 3 & 48 & 63 & 27 & 43 \\
\hline
\end{tabular}

* Primary infection of five female worms in 6-10 week old mice.

$\dagger$ Homologous challenge infection given following extinction of microfilaraemia.

$\ddagger$ Age matched challenge controls.

nd $=$ not done.

\section{Microfilaraemia in $H-2$ congenic mice and $F_{l}$ hybrids}

On the basis of the above results, B10 and BALB/c mice were selected as representative high responder (resistant) and low responder (susceptible) strains respectively. A selection of $\mathrm{H}-2$ congenic mice on the $\mathrm{B} 10$ and $\mathrm{BALB} / \mathrm{c}$ backgrounds were then examined to assess the influence of $\mathrm{H}-2$ haplotype on response phenotype. The strains used and their $\mathrm{H}-2$ haplotypes are listed in Table 1.

$F_{1}$ hybrids were made between resistant and susceptible strains, as listed in Table 2.

In each case six female mice were implanted with five female worms and the results are given in Table 2.

In the congenic strains the microfilaraemia followed the pattern seen in the corresponding background strain, i.e. the response of $B A L B / b$ and $B A L B / k$ was essentially the same as BALB/c, and that of B10.D2/n, B10.BR and B10.G was essentially the same as B10 (Figures $1 \& 2$ ). Thus, no significant influence of the $\mathrm{H}-2$ haplotype on the course of microfilaraemia could be detected.

The pattern of microfilaraemia in $F_{1}$ hybrids followed that of the most responsive parent, i.e. $(\mathrm{NIH} \times \mathrm{B} 10 . \mathrm{G}) \mathrm{F}_{1}$ were essentially the same as B10.G and $(\mathrm{NIH} \times \mathrm{B} 10) \mathrm{F}_{1}$ and $(\mathrm{BALB} / \mathrm{c} \times \mathrm{B} 10) \mathrm{F}_{1}$ were as $\mathrm{B} 10$.

\section{Microfilaraemia in BM radiation chimeras}

Twelve 6-10 week old BALB/c mice were irradiated and six were reconstituted with B10.D2/n BM. Six 6-10 week old B10.D2/n were similarly irradiated and reconstituted 


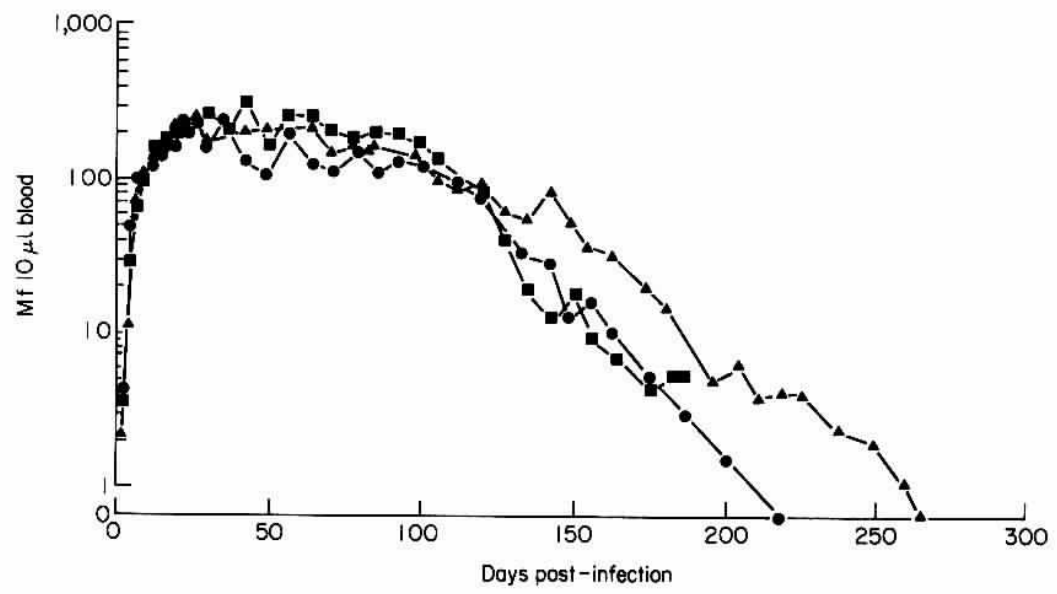

Figure 1. Microfilaraemia in $\mathrm{H}-2$ congenic mice on the BALB/c background following the s.c. implantation of five female D. viteae: $\mathrm{BALB} / \mathrm{b}$

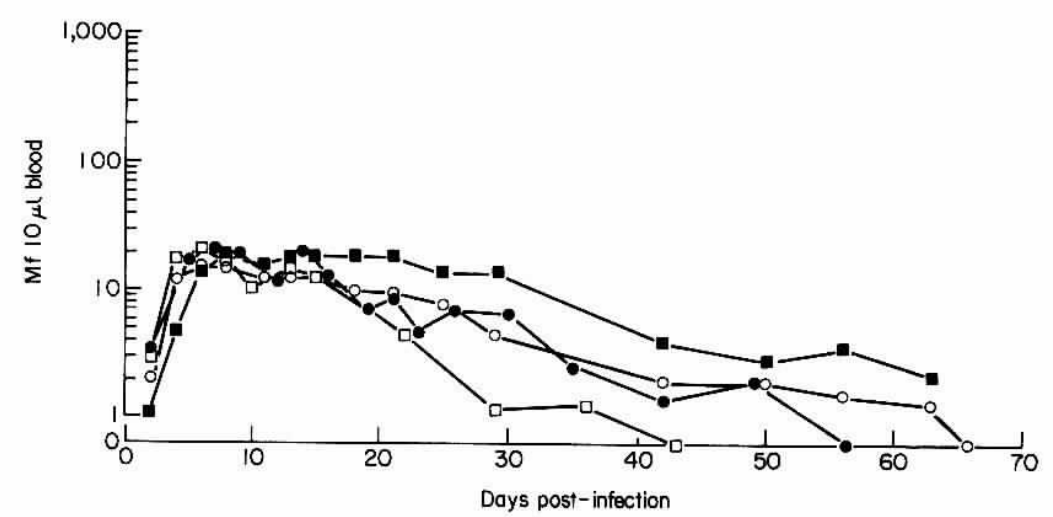

Figure 2. Microfilaraemia in H-2 congenic mice on the B10 background following s.c. implantation

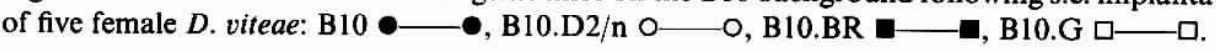

with B10.D2/n BM to provide controls for the effects of irradiation. Unirradiated, age matched BALB/c and B10.D2/n were included as additional controls. The chimeras were allowed to recover and then all the mice were implanted with five female worms. Results are shown in Figure 3.

The microfilaraemias in B10.D2/n mice irradiated and reconstituted with syngeneic BM did not differ significantly from those seen in the controls. However, whereas normal $\mathrm{BALB} / \mathrm{c}$ mice showed the characteristic high and prolonged microfilaraemia, in BALB/c mice reconstituted with B10.D2/n BM, microfilaraemia followed the B10.D2/n type response and was not significantly different from that recorded in syngeneically reconstituted or normal B10.D2/n mice. 


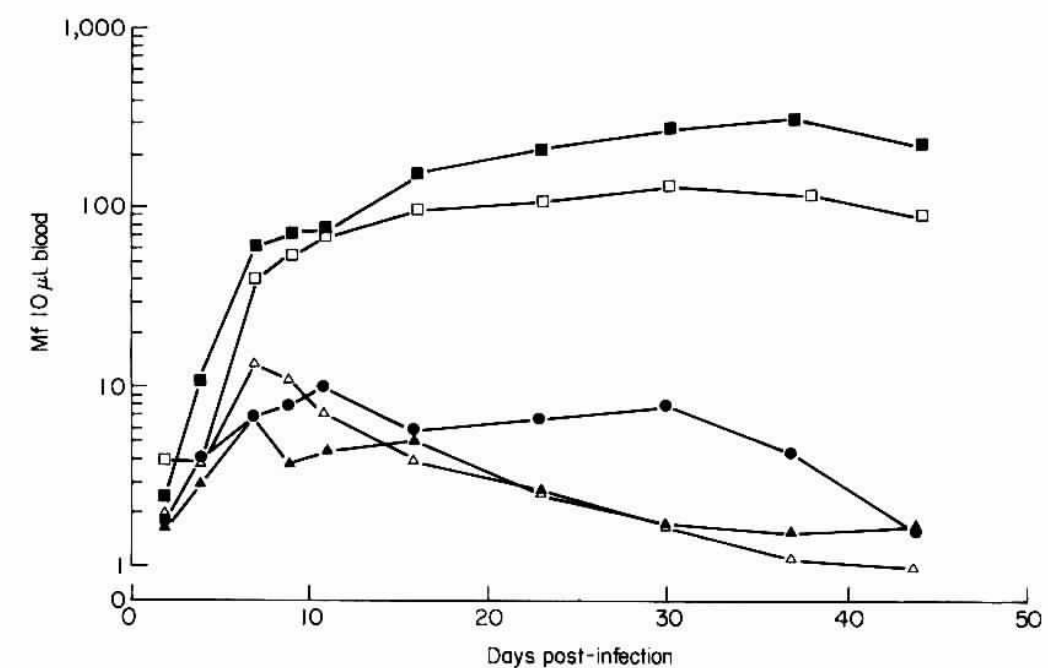

Figure 3. Microfilaraemia in radiation chimaera mice following subcutaneous implantation of five female Dipetalonema viteae: irradiated $\mathrm{BALB} / \mathrm{c}$ reconstituted with $\mathrm{B} 10 . \mathrm{D} 2 / \mathrm{n}$ BM irradiated $\mathrm{BALB} / \mathrm{c}$ reconstituted with BALB $/ \mathrm{c} \mathrm{BM} \square-\square$, normal BALB $/ \mathrm{c} \square \longrightarrow \square$, irradiated B10.D2/n reconstituted with B10.D2/n BM $\triangle-\Delta$, normal B10.D2/n $\Delta-\Delta$.

\section{Discussion}

This study has shown that inbred mouse strains differ in their response to infection with s.c. implanted female $D$. viteae. The microfilaraemia in $\mathrm{B} 10, \mathrm{CBA}$ and $\mathrm{C} 3 \mathrm{H}$ mice was of low level and short duration in comparison with the microfilaraemia in BALB/c mice; $\mathrm{NIH}$ mice demonstrated an intermediate response. The ability to respond rapidly in terms of Mf clearance was inherited as a dominant trait, as demonstrated by the use of $F_{1}$ hybrids, and was not significantly influenced by MHC linked genes. In all strains the adult female worms became depleted of $\mathrm{Mf}$ after about 30 days and were then killed. Hence the low microfilaraemia in B10 mice does not appear to be due to a suppression of $\mathrm{Mf}$ production. In B10 mice microfilaraemia is controlled before the adult worms are killed, whereas the opposite is true for BALB/c mice in which Mf persist long after adult worm death. Thus, independent mechanisms appear to act against adults and microfilariae. When amicrofilaraemic mice were challenged with a homologous infection the resultant microfilaraemia was lower than in age matched controls, and the latter generally exhibited lower microfilaraemias than in the initial primary infections. Hence, all strains appear to develop both age immunity and acquired immunity to infection with $D$. viteae.

Using methods similar to those described here, Haque et al. (1980) found BALB/c mice to be more susceptible (in terms of microfilaraemia) than $\mathrm{C} 57 \mathrm{Bl} / 6$ (B6) mice, with $\mathrm{C} 3 \mathrm{H} / \mathrm{He}$ mice intermediate. Our study found that the response of $\mathrm{C} 3 \mathrm{H} / \mathrm{He}$ was essentially the same as B10 mice which are genetically closely related to B6; this difference in strain designation may be due to substrain variations between the mice used in different laboratories. However, our results also contradict those of Haque et al. (1980) in terms of adult worm survival. Whereas these workers found worms to survive longer in BALB/c mice than in B6 mice, we found worms to survive longer in B10 than in BALB/c. 
Inheritance of resistance to $D$. viteae was dominant in $F_{1}$ hybrids produced by crossing resistant and susceptible strains and this has also been reported for resistance to Brugia malayi $\mathrm{Mf}$ in mice (Fanning et al. 1983). In Bancroftian filariasis, Ottesen et al. (1981) found that the familial clustering of disease in an endemic area was best explained by postulating the existence of a recessive gene for filariasis susceptibility, with frequency $0.82 \pm 0.15$ and a penetrance $0.62 \pm 0 \cdot 14$, such an explanation being twice as likely as the influence of environmental factors.

Our study showed no significant influence of the H-2 haplotype on response phenotype. Resistance to several parasites has been shown to be influenced by genes linked to the MHC (Vadas 1980) but this has not so far been demonstrated for filarial infections. Ottesen et al. (1981) found no significant linkage of susceptibility to Bancroftian filariasis with either HLA-A or HLA-B locus specificities. In rodents, Fanning et al. (1983) found that susceptibility to B. malayi microfilaraemia was independent of H-2 and Cruickshank et al. (1983) found no influence of the RTI (rat MHC) on resistance to infection with $B$. pahangi.

Although a detailed study of the mechanisms through which genetically determined variation in response is expressed was not included within this particular study, the results of the experiments using radiation chimaeras imply that expression is associated with a cell population of BM origin. It cannot be excluded that the early death of transplanted adult worms results from a physiological incompatibility with the murine host, but this is clearly not the cause of the variation in microfilaraemias, which must therefore arise from variation in the ability to mount an effective immune response. The cell populations involved could therefore be lymphoid or myeloid or both, as both antibody-mediated and granulocyte- or macrophage-mediated protective responses are known to operate against D. viteae in rodents (reviewed by Philipp et al. 1984). Analysis of immunological responses during the course of infections in high and low responder mice will form the subject of a subsequent paper.

\section{Acknowledgements}

This work was supported by a grant from the Wellcome Trust (No. 11855).

\section{References}

Cruickshank J.K., Price K.M., Mackenzie C.D., Spry C.J.F. \& Denham D.A. (1983) Infection of inbred and nude (athymic) rats with Brugia spp. Parasite Immunology 5, 527

FANNING M.M. \& KazURA J.W. (1983) Genetic association of murine susceptibility to Brugia malayi microfilaraemia. Parasite Immunology 5, 305

Fox E.G. \& SCHACHER J.F. (1976) A comparison of syngeneic laboratory rat strains as hosts for Brugia pahangi. Transactions of the Royal Society of Tropical Medicine and Hygiene 70, 523

Gusmao R.D'A., StANLEy A.H. \& OTtESEN E.A. (1981) Brugia pahangi: immunologic evaluation of the differential susceptibility to filarial infection in inbred Lewis rats. Experimental Parasito$\log y 52,147$

Haque A., Worms M.J., Ogilvie B.M. \& Capron A. (1980) Dipetalonema viteae: microfilariae production in various mouse strains and in nude mice. Experimental Parasitology 49, 398

Low C.C. (1908) The unequal distribution of filariasis in the tropics. Lancet i, 279 
NeILson J.T.M. (1978) Primary infections of Dipetalonema viteae in an outbred and five inbred strains of golden hamsters. Journal of Parasitology 64, 378

OGILVIE B.M. \& MACKENZIE C.D. (1981) Immunology and immunopathology of infections caused by filarial nematodes. In Parasitic Diseases. The Immunology, ed. by J. Mansfield. p.227, Marcel Dekker, New York

Ottesen E.A., Mendell N.R., Macqueen J.M., Weller P.F., Amos D.B. \& Ward F.E. (1981) Familial predisposition to filarial infection-not linked to HLA-A or -B locus specificities. Acta Tropica 38, 205

Philipp M., Worms M.J., Maizels R.M. \& OGILvie B.M. (1984) Rodent models of filariasis. In Contemporary Topics in Immunobiology, Vol. 12, ed. by J.J. Marchalonis. p.275. Plenum Publishing Corporation

Piessens W.F., McGreevy P.B., Ratiwayanto S., McGreevy M., Piessens P.W., Koiman I., SAROSO J.S. \& DENNIS D.T. (1980) Immune responses in human infections with Brugia malayi: correlation of cellular and humoral reactions to microfilarial antigens with clinical status. American Journal of Tropical Medicine and Hygiene 29, 563

VADAs M.A. (1980) Parasite immunity and the major histocompatibility complex. Immunogenetics 11,215

WAKELIN D. (1978) Genetic control of suspeptibility and resistance to parasitic infections. Advances in Parasitology 16, 219

Worms M.J., Terry R.J. \& Terry A. (1961) Dipetalonema witei, filarial parasite of the jird, Meriones libycus. I. Maintenance in the laboratory. Journal of Parasitology 47, 963 